\title{
GREGOR, M. Rímsky štát a právo za vlády cisára Augusta.
}

Praha: Leges, 2018, 200 s.

Vláda císaře Augusta se do dějin starověkého Říma zapsala jako období počátku principátu, v němž došlo k proměně občanskými válkami poznamenané republiky v císařství. Charakteristická je pro ni však také řada reforem, které se dotkly snad každého právního odvětví. Na oba aspekty se ve své nové knize Rímsky štát a právo za vlády cisára Augusta zaměřuje JUDr. Martin Gregor, Ph.D., odborný asistent na Katedře římského práva, kanonického práva a církevního práva Právnické fakulty Univerzity Komenského v Bratislavě. Odborné veřejnosti je již autor dobře znám. Ve své vědecké činnosti se zabývá jak římským právem, především veřejným, rodinným a procesním, tak konfesním právem ve slovenském i mezinárodním měřítku. Vystoupil na řadě slovenských i mezinárodních vědeckých konferencí, kde okamžitě zaujal pozornost posluchačů svým neskrývaným vědeckým zápalem, který se také projevuje mimořádnou publikační aktivitou. Nyní předkládá výsledky svého vědeckého zkoumání v knize, jež má potenciál popularizovat obor ř́mského práva za hranicemi akademické půdy.

Na císaře Augusta je možné nahlížet různými pohledy. Na základě literárních památek antických historiků si lze představovat jeho veřejné vystupování a charakter. Do dějin spásy se zapsal jako panovník, za jehož vlády se, jak uvádí Bible, narodil Ježíš Kristus. Lidé v současnosti si jej mnohdy mimoděk připomínají pojmenováním měsíce srpna ve slovenštině, angličtině nebo třeba němčině. Autor publikace však již v úvodu připomíná, že zkoumání osobnosti císaře Augusta a jeho lidské povahy je úkolem historie, nikoli práva. V oboru římského práva si však lze všímat toho, jak jeho působení změnilo uspořádání římského státu, a jaký byl obsah jím provedených reforem. Představovaná kniha se pouští do rozboru změn ústavního, správního, trestního, procesního i rodinného práva, díky čemuž může Augustovy reformy prezentovat komplexně a ve vzájemném kontextu. Obzvláště přínosné je zaměření pozornosti na oblast veřejného práva, především práva trestního, které bývá často právními romanisty opomínáno. Při výkladu a hodnocení Augustových zákonů se autor musel vyrovnat s nedokonalostí současných vědeckých poznatků. Pro zkoumání římského práva je skutečně charakteristické, že na rozdíl od oborů platného práva nelze pracovat $\mathrm{s}$ úplným zněním právních předpisů, a místo toho je nutné obsah právních norem skládat jako mozaiku z nejrůznějších pramenů. Tato kniha si je těchto úskalí vědoma a autor sám přiznává, že jeho cílem nebylo přesvědčivě vyřešit konflikty protichůdných teorií a hypotéz, které v souvislosti s působením císaře Augusta vznikly. To ostatně ani není možné. Je ovšem významné, že publikace existující teorie sumarizuje a předkládá čtenáři. 
Kniha se mimo úvodu a závěru člení na šest kapitol. Zatímco první z nich poskytuje historický úvod, následující kapitoly se zaměřují na konkrétní Augustovy reformy v jednotlivých odvětvích práva. Každá kapitola se věnuje jednomu z nich, člení se přitom ještě na několik tematicky užších podkapitol.

Nejprve je čtenář seznámen s událostmi, které předcházely nástupu císaře Augusta k moci. Kapitola je sice uvozena Augustovým životopisem, v průběhu ale přechází v popis dějinných událostí Římské říše, což odpovídá postupnému prolínání života budoucího císaře s vývojem státu. Mapuje Augustovo nabývání moci, veřejné funkce, jež zastával, soupeření o vládu i vojenské výpravy, kterých se účastnil. Nechybí ani informace o Augustově soukromém životě. Autor rozebírá také právní aspekty některých událostí, např́iklad platnost adopce Caesarem nebo otázku falšování listin.

Druhá kapitola se již zaměřuje na odvětví ústavního práva, nicméně, navazuje na předchozí tím, že si všímá právního základu nově vznikajícího principátu. Rozebírá státní zřízení z pohledu státovědy a ústavního práva, zkoumá právní zakotvení Augustových pravomocí. Dochází k závěru, že principát není možné přirovnávat k jiným známým formám vlády, protože s sebou přinášel mnohá specifika. Autor také připomíná nevyjasněné pochybnosti o tom, nakolik principát následoval ústavní tradice republiky, a v jaké míře se od nich odkláněl. Dále podrobně popisuje průběh vzniku principátu a jednotlivé kroky, jimiž Augustus nabýval pravomoci, což je významné pro definici postavení jeho nástupců.

Ve třetí kapitole se autor soustředí na reformy správního práva. Zformování nového ústavněprávního uspořádání $\mathrm{v}$ podobě principátu musely následovat změny organizační struktury státní správy. Augustus v duchu dualistického uspořádání zrrídil vedle dosavadních republikánských úruadů i soustavu úřadů císařských. Zatímco na první vykonával vliv nepř́mo, druhá mu podléhala zcela. Publikace však upozorn̆uje na to, že systém úřadů, u jehož zrodu Augustus stál, následně procházel dvousetletým vývojem, v němž zanechala svou stopu řada jeho nástupců. Zvláštní pozornost je věnována reformě správy provincií a proměně jejich vztahu s Ř́mem. Autor vnímá rostoucí důraz na rozvoj provincií, které již dále neměly být pouhým předmětem vykořist'ování. Dále je pojednáno o úřadu římských prefektů, kurátorů, prokurátorů a také o finanční a daňové správě za císaře Augusta, která byla nezbytnou podmínkou řádného fungování státního aparátu.

Zatímco dosud představené kapitoly prostupuje tématika státního zřízení a distribuce moci, druhá polovina knihy se zaměřuje na reformy, jimiž chtěl císař Augustus obnovit vnitřní pořádek a bezpečnost, tak narušené dlouhými občanskými válkami. Nepokoje předcházející počátku principátu se sebou přinesly i mravní úpadek, který chtěl císař zastavit. Neváhal použít nástroje trestního práva, jehož reformou se zabývá čtvrtá kapitola. Podrobně představuje zákon o násilí, zákon o trestání cizoložství a zákon o volebních machinacích. Již z názvů těchto předpisů vyplývá, že se Augustova pozornost nesoustředila jen na předcházení násilným činům, ale také na zachování celistvosti starořímské rodiny, mimo jiné i náboženského svazku, jehož porušení působilo nepřízeň ochranných bohů. Podobně také volební korupce patřila v té době k palčivým problémům, který nabíral masových měřítek. $V$ př́padě všech tř́i předpisů je třeba ocenit, že se autor neomezuje na prosté líčení jejich obsahu, ale zasazuje je do kontextu historického vývoje a společenské situace.

Pátá kapitola se věnuje reformě procesního práva a soudnictví. Popisuje změny organizace soudnictví i vývoj procesních institutů, které byly provedeny Juliovým zákonem 
o soukromém soudnictví a Juliovým zákonem o veřejném soudnictví. Bohužel ani jeden z nich se dodnes nezachoval, a proto je velmi obtížné rekonstruovat jejich obsah, obzvláště kvůli závislosti na mimoprávních pramenech. Vyvstávají také pochyby o formální stránce procesních zákonů, na které autor upozorňuje a předkládá východiska, k nimž dochází právní věda.

V poslední kapitole jsou čtenáři seznámeni s reformou občanského života, hnanou Augustovou touhou obnovit dávné rrímské tradice a povznést mravy. Zasahoval do způsobu oblékání, Juliův zákon o přepychu reguloval náklady vynaložené na soukromé hostiny. Především se však císař zaměřil na obnovení vážnosti tradiční římské rodiny. Mezi kontroverzní opatření patřila povinnost žít po určitou dobu života v manželství, stanoven byl také minimální počet dětí a rozšířeny překážky uzavírání manželství. Změny se však týkaly také postavení otroků, v souvislosti s nimi se publikace zaměřuje na vztahy s jejich pány. Představuje podrobněji senatusconsultum Silanianum, které reagovalo na vzrůstající nedůvěru v otroky a obavy ze vzpour a rebelií. Otroci byli proto př́sně vedeni k povinnosti chránit svého pána a nedovolit si proti němu vystoupit.

Za závěr, v němž autor hodnotí výsledky výzkumu, je zařazen obsáhlý přehled použité literatury. Odděleně jsou v něm prezentovány původní právní prameny, neprávní prameny, dále monografie, učebnice, encyklopedie, a poté periodická literatura s př́íspěvky ve sbornících. Nejen během čtení publikace přijde vhod chronologický přehled předpisů vydaných během Augustovy vlády zařazený nakonec.

Publikace je určena jednak pro širokou veřejnost, kterou poutavě seznamuje s obdobím vlády císaře Augusta a jeho důsledky, pro studenty práv a historie pak bude vhodným doplněním studijních materiálů. Osloví jistě i veřejnost odbornou, a to vysokou úrovní zpracování a rozsáhlým poznámkovým aparátem, který odkazuje na velké množství pramenů a především zahraniční literatury. Právě ve zprostředkování poznatků obsažených $\mathrm{v}$ zahraniční literatuře, stejně jako $\mathrm{v}$ jejím přehledném souhrnu, lze spatřovat jeden $\mathrm{z}$ př́ínosů této publikace.

Předkládaná kniha poskytuje mimořádně široký a komplexní pohled na právní aspekty působení císaře Augusta a na jím prováděné reformy. Je z ní patrné na čtenáře přenositelné nadšení autora pro toto téma i jeho hluboké znalosti. Není divu, když autor sám přiznává, že se tématu věnuje již od počátků své vědecké činnosti. Publikace představuje vítaný zdroj poznání o právu v jednom z nejdůležitějších období starověkého Říma.

doi: $10.14712 / 2464689 X .2019 .14$

Marek Novák 